\title{
Letters of Alliance and an Alliance of Letters: Aeneas Silvius Piccolomini, Juan de Carvajal, and the Conciliar Crisis
}

\author{
EMILY O'BRIEN
}

Simon Fraser University

\begin{abstract}
This contribution charts a new pathway in the correspondence between Aeneas Silvius Piccolomini (1405-64) and Juan de Carvajal (1399?-1469) by focusing primarily on the relationship between the two men. It argues that each sought to adjust their relationship to fit the political demands of the moment, and that they used it, or tried to use it, as a tool to navigate and even resolve the conciliar crisis. This article enriches our understanding of a critical moment in church history, sharpens our grasp of the roles of both Piccolomini and Carvajal, and suggests new ways that humanism contributed to the fifteenth-century church.
\end{abstract}

Cette contribution offre un nouvel aperçu de la correspondance entre Aeneas Silvius Piccolomini (1405-1464) et Juan de Carvajal (1399?-1469), en s'intéressant principalement à la relation entre les deux hommes. Elle démontre que ces auteurs cherchaient tous deux à ajuster leur relation en fonction des exigences politiques du moment et aussi qu'ils ont cherchéà s'en servir, ou qu'ils s'en sont effectivement servi, dans le but d'affronter ou de résoudre la crise conciliaire. Cet essai approfondit notre compréhension d'un moment critique de l'histoire de l'Église, illustre le rôle que Piccolomini et Carvajal ont joué lors de cet événement, et ouvre vers la voie vers de nouvelles manières dont l'humanisme a pu contribuer à l'Église du quinzième siècle.

70 anyone who has studied the history of conciliarism, Juan de Carvajal (1399?-1469) and Aeneas Silvius Piccolomini (1405-64) stand out as familiar, important, and interconnected names. Both men saw their careers defined by the conciliar crisis of the mid-fifteenth century, when for almost two decades the Council of Basel (1431-49) and Pope Eugenius IV (r. 1431-47) vied for supreme authority in the western church. ${ }^{1}$ While each man followed a different path through that crisis, they both played prominent roles therein. Carvajal did so as one of Eugenius's - and the papal monarchy's—most stalwart

1. On the Council of Basel and its battle with Eugenius, see especially Joachim Stieber, Pope Eugenius IV, the Council of Basel, and the Secular and Ecclesiastical Authorities in the Empire: The Conflict over Supreme Authority and Power in the Church (Leiden: Brill, 1978); Johannes Helmrath, Das Basler Konzil, 1431-1449 (Cologne: Böhlau, 1987); and Michiel Decaluwé, Thomas M. Izbicki, and Gerald Christianson, eds., A Companion to the Council of Basel (Leiden: Brill, 2016). 
defenders in the face of the conciliar challenge. ${ }^{2}$ A celebrated Castilian canonist, Carvajal was trained in law at Salamanca and took holy orders in the early 1430s. As dean of Astorga, he distinguished himself conducting business in Spain on behalf of Eugenius IV and was soon rewarded with an appointment at the papal court. By 1438, he was serving in the curia as auditor of the Rota and as an occasional ambassador within Italy. ${ }^{3}$ But when tensions between pope and council evolved into schism, his role quickly transformed. In 1440, not long after the council fathers had declared Eugenius deposed, Carvajal was dispatched from Rome to Germany. As one of Eugenius's chief legates, his mission was formidable: to convince emperor-elect Frederick III, together with Germany's princes, to reject the Council of Basel's claims to legitimacy and sovereignty and to recognize Eugenius, and the papacy more generally, as sole and supreme head of the church. Carvajal's contributions to this process of reconciliation proved crucial: in 1447, he helped broker the agreement that reconciled Frederick with Eugenius IV; and a year later, he served as chief architect of the Concordat of Vienna (1448). ${ }^{4}$ These achievements earned Carvajal swift promotion to the college of cardinals and launched what was to be a long and distinguished diplomatic career on the European stage. ${ }^{5}$ They also cemented his position of influence in the Roman curia, where he remained a staunch advocate of papal

2. The fullest scholarly treatment of Carvajal and his career is Lino Gómez Canedo, Un Español al servicio de la Santa Sede: Don Juan de Carvajal, cardenal de Sant'Angelo, legado en Alemania y Hungria, 1399-1469 (Madrid: Instituto Jeronimo Zurita, 1947). More narrative than analytical, Gómez Canedo’s study has received little scholarly attention or esteem. It remains, however, the only modern monograph on Carvajal and is a useful source, both for its details on Carvajal's career in the Roman curia and for the writings by and about Carvajal published in its appendices. Before Gómez Canedo's study, the main source for information about Carvajal was Domenico Lopez de Barrera, De rebus gestis Joannis cardinalis Carvajalis commentarius (Rome, 1752). For a recent overview of Carvajal's career, see Thomas Izbicki, "Carvajal, Juan de," in Medieval Iberia: An Encyclopedia, ed. E. Michael Gerli (London and New York: Routledge, 2003), 207-08.

3. Carvajal's years in Spain and his early career in the Roman curia have received little attention. For the most thorough discussion, see Gómez Canedo, 31-40.

4. The agreement set out the empire's relationship with the Roman Church. For Carvajal's role both in reconciling Frederick with Eugenius and in framing the terms of the concordat, see especially Stieber, $277-322$.

5. Carvajal became Bishop of Plasencia in 1446 and was promoted to the rank of cardinal that same year. See Gómez Canedo, 100. 
monarchy through the pontificates of Eugenius's successors-including that of Pope Pius II (1458-64), Aeneas Silvius Piccolomini. ${ }^{6}$

It was two decades earlier, and under very different circumstances, that Carvajal and Piccolomini's careers first became closely intertwined. When Carvajal first arrived in Germany in January 1441, he likely knew Piccolomini from his considerable accomplishments at Basel. It was there at the council that the young humanist had launched his career in 1432, serving first as secretary to a succession of prelates and then as the assembly's abbreviator major. In that capacity, Piccolomini had drafted the council's correspondence and documents, and in the period of its most heated clashes with Eugenius. In 1437, when the pope declared the council transferred to Ferrara, Piccolomini remained in Basel with the majority of the fathers and in defiance of Eugenius's command. In 1439, he served as master of ceremonies at the conclave that elected rival pope Felix V and, shortly thereafter, was appointed Felix's secretary and publicist. ${ }^{7}$ Among the works he wrote in that post and in the Basel council's defence was the Libellus dialogorum de generalis concilii auctoritate et gestis Basiliensium (November-December 1440). A collection of fourteen short dialogues, the Libellus dialogorum featured as one of its chief interlocutors Nicholas of Cusa (1401-64), one of the most celebrated theologians, canon lawyers, and philosophers of the fifteenth century and, in Piccolomini's words, the "Hercules of the Eugenians." It was a work that Carvajal would have known at least by

6. On Carvajal's extensive diplomatic career after 1448, see especially Gómez Canedo, 111-251. See also Emily O'Brien, The Commentaries of Pope Pius II (1458-1464) and the Crisis of the FifteenthCentury Papacy (Toronto: University of Toronto Press, 2015), 68-74; Norman Housley, Crusading and the Ottoman Threat, 1453-1505 (Oxford: Oxford University Press, 2012), 109-16, 122; Frederick Heymann, George of Bohemia: King of Heretics (Princeton: Princeton University Press, 1965), 36-40. For a broader discussion of papal legates in the late medieval period, see Antonín Kalous, Late Medieval Papal Legation: Between the Councils and the Reformation (Rome: Viella, 2017).

7. On Piccolomini's years at the Council of Basel, see especially Thomas M. Izbicki, Gerald Christianson, and Philip Krey, introduction to Reject Aeneas, Accept Pius: Selected Letters of Aeneas Sylvius Piccolomini (Pope Pius II) (Washington, DC: Catholic University Press, 2006), 9-26, and Barbara Baldi, Il "cardinale tedesco": Enea Silvio Piccolomini fra impero, papato, Europa (1442-1455) (Milan: Edizioni Unicopli, 2012),19-35.

8. Enea Silvio Piccolomini, Libellus dialogorum, ed. Simona Iaria (Rome: Edizioni di Storia e Letteratura, 2016). For a discussion of this text, see Simona Iaria, "Diffusione e recezione del Libellus dialogorum di Enea Silvio Piccolomini," Italia Medioevale e Umanistica 44 (2003): 65-114, and O’Brien, The Commentaries of Pope Pius II, 47-54. The reference to "Hercules [...] omnium Eugenianorum" comes 
reputation, for Cusanus was none other than Eugenius's other legate on the ground in Germany. ${ }^{9}$

It is not clear when Carvajal and Piccolomini first met, but we do know their paths began to cross regularly in 1443, after the latter had left Basel and had accepted a post in the imperial chancery. ${ }^{10}$ As Frederick's secretary and, increasingly, as his advisor and envoy, Piccolomini at that point supported the emperor's policy of neutrality in the conflict between Eugenius and the Basel assembly. He tirelessly promoted Frederick's plan for peace in the church, and in 1446 and 1447 took part in the lengthy negotiations with Eugenius's legates, including Carvajal, that restored the emperor to full obedience to the Roman Church. ${ }^{11}$ Carvajal and Piccolomini were not always in the same camp during this period, but they often worked side by side-at the imperial court, at the Roman curia, and at a string of diets convened to resolve the schism. When they were not in the same location, they corresponded with one another in writing. ${ }^{12}$ These letters, while private in a formal sense, remained consistently focused on the public affairs in which they were embedded. ${ }^{13}$ Their correspondence

from Piccolomini's first history of the Council of Basel, De gestis concillii Basiliensis commentariorum, libri II, ed. Denys Hay and W. K. Smith (Oxford: Clarendon Press, 1978), 14.

9. Cusanus himself not only knew the work; between February and April 1441, he penned his own dialogue in response: The Dialogue against the Amadeists. For a modern edition with English translation, see Thomas M. Izbicki, ed., Nicholas of Cusa: Writings on Church Reform (Cambridge, MA: Harvard University Press, 2008), 272-333.

10. Piccolomini moved to Wiener-Neustadt in January 1443. The first chance for Carvajal and Piccolomini to meet appears to have been a few months earlier at the Diet of Frankfurt (June-August 1442). The two almost certainly encountered one another at the imperial court before October 1443. Many years later, in a papal bull retracting his conciliarist writings (In minoribus agentes, issued April 1463), Piccolomini specifically refers to conversations he had that year with Carvajal when the legate was visiting Frederick. See C. Fea, Pius II Pont. Max. a calumniis vindicatus (Rome, 1823), 159.

11. For a recent and detailed discussion of Piccolomini's years at the imperial court, see Baldi, Il “cardinale tedesco." See also, O’Brien, The Commentaries of Pope Pius II, 54-73, 86-94.

12. There are only four extant letters from this early period of their correspondence (October 1443; May 1444; March 1446; April 1447), in part because they were so often together.

13. The challenge of separating public from private in Piccolomini's correspondence is taken up by Barbara Baldi, "La corrispondenza di Enea Silvio Piccolomini fra 1431 e 1454. Una maturazione di un'esperienza fra politica e cultura," Reti Medievali Riviste 10 (2009): 293-314. For a discussion of the same theme in humanist epistolography more generally, see Claudio Griggio, "Dalla lettera all'epistolario: aspetti retorico-formali dell'epistolografia umanistica," in Alla lettera: teorie e pratiche epistolari dai Greci al Novecento, ed. Adriana Chemello (Milan: Guerini e Associati, 1998), 88-89. 
continued as both men rose through the church hierarchy, and after the former ascended the papal throne as Pope Pius II in 1458. In all, we have dozens of their letters spanning more than two decades. They include two of Piccolomini's most important writings, which he set in epistolary frameworks and addressed to Carvajal: a history of the Council of Basel, De rebus Basiliae gestis commentarius (1450), and a dialogue set in the wake of Constantinople's fall, Dialogus de somnio quodam (1453-57?). ${ }^{14}$ This rich correspondence attests to more than a sustained professional association: it reveals the lasting friendship and intellectual exchange that grew up alongside it.

Given the stature of both men, the wealth of sources, and the significance of the events with which they were involved, the relationship between Piccolomini and Carvajal would seem a natural line of historical inquiry. Yet scholars have left it largely unexplored. Their reasons include a source base that, while extensive, is incomplete: we have dozens of Piccolomini's letters to Carvajal (and many published in modern editions), but of those Carvajal wrote to Piccolomini, only one has survived. ${ }^{15}$ Complicating this challenge further is the fact that almost none of Carvajal's other writings, including several works

14. Most of Piccolomini's extant correspondence with Carvajal between 1443 and 1454 has been published in modern editions. See especially Rudolf Wolkan, ed., Der Briefwechsel des Eneas Silvius Piccolomini, in Fontes Rerum Austriacarum, Diplomataria et Acta, ser. 2, vols. 61, 62, 67, 68 (Vienna, 1909-18), which includes thirty-four letters to Carvajal (most of which date to after 1450); Giuseppe Cugnoni, ed., Aeneae Silvii Piccolomini Senensis qui postea fuit Pius II P.M. Opera inedita (Rome: Salviucci, 1883); and Adrianus Van Heck, ed. Epistolarium seculare: complectens De duobus amantibus, De natura equorum, De curialium miseriis, in Studi e Testi 439 (Vatican City: Biblioteca Apostolica Vaticana, 2007). For other letters dating to this period, see Epistolae seculares et pontificales (Cologne: A. ther Hoernen, ca. 1480), and Gómez Canedo, 323-35. For an English translation of selected letters to Carvajal, including Piccolomini's revised history of the Council of Basel (1450), see Izbicki, Christianson, and Krey, eds., Reject Aeneas. For the dialogue he addressed to Carvajal, see Duane R. Henderson, ed., Dialogus (Hanover: Hahnsche Buchhandlung, 2011). For Piccolomini's letters to Carvajal during his cardinalate and pontificate, see especially Aeneae Sylvii Piccolominei senensi ... opera quae extant omnia (Basel: Henricum Petri, 1551; repr., Frankfurt: Minerva, 1967); and Odericus Raynaldus, ed., Annales Ecclesiastici, vol. 29 (Lucca: Leonardo Venturini, 1753). To date, there exists no complete inventory of Piccolomini and Carvajal's correspondence.

15. Wolkan, ed., 68:564-65. The letter is dated 13 February 1453. For Piccolomini's letters to Carvajal, see note 14. For an overview of his correspondence and related scholarship, see Baldi, "La corrispondenza," 293-314. 
written in defence of papal sovereignty, have come down to us. ${ }^{16}$ With so few of his documents to work with, reconstructing his relationship with Piccolomini becomes an exceptionally complex project. Traditions of scholarship also help to explain the lack of interest in this topic. For historians of conciliarism, events and ideas-not personal or professional relationships-have long been the primary focus of study. ${ }^{17}$ Indeed, it is with the aim of exploring these dimensions of church history that Piccolomini's correspondence with Carvajal has most often been mined. ${ }^{18}$ Scholars of Piccolomini himself have taken a similar approach, scrutinizing these letters almost exclusively as records of his actions and still more as reflections of his thought: his views on ecclesiastical authority; his understanding of contemporary politics; his relationship with the curia; and his vision of empire and state-building. ${ }^{19}$ In the context of these

16. See Gómez Canedo, 272-74. Gómez Canedo conducted an exhaustive search of European libraries and archives for Carvajal's writings. For an edition of the single extant papal apology by Carvajal, and for a letter of similar substance, see Gómez Canedo, 277-98 and 337-44.

17. See, for example, Antony Black, Monarchy and Community: Political Ideas in the Later Conciliar Controversy (Cambridge: Cambridge University Press, 1970) and Council and Commune: The Conciliar Movement and the Fifteenth-Century Heritage (London: Burns and Oates, 1979); Stieber, Pope Eugenius IV; Brian Tierney, Foundations of the Conciliar Theory: The Contribution of the Medieval Canonists from Gratian to the Great Schism, rev. ed. (Leiden: Brill, 1998); Francis Oakley, The Conciliarist Tradition: Constitutionalism in the Catholic Church, 1300-1870 (Oxford: Oxford University Press, 2003); and Michiel Decaluwé, A Successful Defeat: Eugene IV's Struggle with the Council of Basel for Ultimate Authority in the Church (Turnhout: Brepols-Institut Historique Belge de Rome, 2009). For a more wideranging analysis of the conciliar movement in the fifteenth century, see especially Helmrath, Das Basler Konzil.

18. See, for example, Stieber, 262, 266; Martin Davies, "Juan de Carvajal and Early Printing: The 42-line Bible," The Library 18, ser. 6, no. 3 (September 1996): 193-215; Housley, Crusading and the Ottoman Threat, 73, 84; Marcela K. Perett, Preachers, Partisans and Rebellious Religion: Vernacular Writing and the Hussite Movement (Philadelphia: University of Pennsylvania Press, 2018), 197-203.

19. See, for example, William Boulting, Aeneas Silvius (Enea Silvio de'Piccolomini-Pius II): Orator, Man of Letters, Statesman, and Pope (London: Archibald Constable and Company, 1908), 130, 188, 204, 224 25, 228, 278; Cecilia Ady, Pius II (Aeneas Silvius Piccolomini) the Humanist Pope (London: Methuen, 1913), 111-12, 174, 293-94, 305-06; Barbara Baldi, "La Boemia ussita in una lettera di Enea Silvio Piccolomini a Giovanni Carvajal (21.8.51): fra esperienza diplomatica e riflessione storico-politica," in Lontano da dove. Sensazioni, aspirazioni, direzioni, spazi fra Quattrocento e Seicento, ed. Barbara Baldi and Maria Matilde (Milan: Unicopli, 2009), 13-40; Baldi, Il "cardinale tedesco"; Luigi Totaro, "Gli scritti di Enea Silvio Piccolomini sul concilio," in Conciliarismo, stati nazionali, inizi dell'umanesimo: atti del XXV convegno storico internazionale, Todi, 9-12 ottobre 1988 (Spoleto: Centro di Studi sull'Alto Medioevo, 1990), 47-78; Emily O’Brien, “Aeneas Sylvius Piccolomini and the Histories of the Council 
studies, Carvajal, as Piccolomini's interlocutor, becomes an incidental if not an altogether invisible figure. The relationship between the two men is merely sketched, if it is discussed at all; and because scholars draw their information about Carvajal from either Piccolomini's own apologetic writings or those of his political allies, that sketch often proves unreliable. ${ }^{20}$

This article charts a new pathway into Piccolomini and Carvajal's correspondence by making their relationship its primary focus. Its aim is to understand what the nature of that relationship was, how it was forged in the crucible of the conciliar crisis, and what, if anything, it contributed to that conflict or its resolution. Its methodology will necessarily be different from that of existing scholarship on their letters. For one, it will read these texts as part of a conversation; and thus, when analyzing Piccolomini's words, it will endeavour to listen as much for Carvajal's voice as for that of the author. It also starts from the premise that Piccolomini and Carvajal's relationship was dynamic and that it was shaped first and foremost by the fast-moving ecclesiastical crisis in which they were working. An understanding of those dynamics can come only through a close attention to context; and thus, each letter must be carefully positioned in the particular historical moment from which it emerged. In keeping with these methodological criteria, and with the parameters of a journal article in mind, this essay will focus on a single letter-the first in the extant correspondence between Piccolomini and Carvajal. It thus represents only the beginning of a much longer investigation. But an analysis of even one letter can be remarkably revealing. This article will illuminate just how complex the relationship between

of Basel," in The Church, the Councils and Reform: A Fifteenth-Century Legacy, ed. Gerald Christianson, Thomas M. Izbicki, Christopher M. Bellitto (Washington, DC: Catholic University Press, 2008), 73-80; and Jesse Mann, "Histories of the Council," in Decaluwé, Izbicki, and Christianson, eds., 62-64. For recent investigations that pay closer attention to Piccolomini's relationship with Carvajal, see especially Alessandro Scafi, "Enea Silvio Piccolomini e Juan de Carvajal: un sogno tra diplomazia e letteratura," in Rapporti e scambi tra umanesimo italiano e umanesimo europeo, ed. Luisa Rotondi and Secchi Tarugi (Milan: Editrice Nuovi Orizzonti, 2001), 665-77; and O'Brien, The Commentaries of Pope Pius II, 66-69. 20. See, for example, Ady, 240-42; Boulting, 316, 346, 352-53; Scafi, 672-73. Ludwig von Pastor, The History of the Popes from the Close of the Middle Ages, ed. Frederick Ignatius Antrobus, $5^{\text {th }}$ ed., 36 vols. (London: Kegan Paul, 1894), 4:131-34. In addition to Piccolomini's own Commentaries, scholars have turned most often for this information to the writings of his nephew, Cardinal Jacopo Ammannati Piccolomini. See Pii Secundi Pontificis Maximi commentarii rerum memorabilium ... quibus hac editione accedunt Jacobi Picolominei, Cardinalis Papiensis commentarii ... eiusdemque epistolae perelegantes (Frankfurt, 1614), 354-55, 453-54. 
Carvajal and Piccolomini was. It will argue that they each sought to shape it to the political demands of the moment. And it will show they used it-or sought to use it-as a tool to navigate and even resolve the conciliar crisis. Along the way, this article will also complicate our understanding of a critical moment in church history, sharpen our grasp of both Piccolomini's and Carvajal's roles therein, and illuminate the role humanism played in resolving the conciliar crisis.

Dated 23 October 1443, the letter at the centre of our investigation belongs to an important but often overlooked moment in conciliar history. ${ }^{21}$ Piccolomini wrote it a few weeks before the emperor was to convene the Diet of Nuremberg, or more accurately, to reconvene it: the assembly had originally been scheduled for February-nine months before. ${ }^{22}$ There, representatives of Felix V, the Council of Basel, and Eugenius were to meet with the emperor, German princes, and their ambassadors. The task at hand was to discuss the idea of summoning a new, undoubted council to resolve the schism. Initially proposed by the emperor, the new or "third" council solution had already won the endorsement of all the imperial electors at the Diet of Frankfurt the previous August. ${ }^{23}$ The November Diet of Nuremberg was one among many called by Frederick III to bring peace to the church; and like so many other such assemblies, this one produced no results-in large part because the man who had summoned it failed to attend. ${ }^{24}$ Judged a failure by participants and historians alike, this second Nuremberg diet is crowded out of most historical accounts by discussions of the assembly's third and most productive iteration

21. Wolkan, ed., 61:208-11. For an English translation, see Izbicki, Reject Aeneas, 171-75. All translations are mine unless otherwise noted. The letter is summarized, excerpted, and briefly discussed in Gómez Canedo, 66-67; and Baldi, Il "cardinale tedesco," 68-69. Baldi reads it as an expression of Piccolomini's current views on the conciliar crisis. Gómez Canedo identifies the friendly and frank debate in the letter as typical of their relationship.

22. On the first Nuremberg diet (2-16 February 1443), see Stieber, 252, 264; and Gómez Canedo, 55-56. The November diet was scheduled to begin on the eleventh of the month, but the opening was delayed until the twenty-sixth (Stieber, 265).

23. On the "third" council proposal and on the Diet of Frankfurt (June-August 1446), see especially Stieber, 215-46.

24. The November Nuremberg diet adjourned 22 January 1444. Stieber, 265. 
in the fall of $1444 .{ }^{25}$ But when Piccolomini wrote to Carvajal in late October 1443 , there were no plans for a third diet because no one was predicting the second one would fail. Indeed, from Piccolomini's and Carvajal's perspective, the November assembly had the potential to be a defining moment in the history of the church. Mid-October 1443 was a time of acute crisis in Eugenius's relationship with Germany, and with the emperor specifically, and a crisis in which both Piccolomini and Carvajal were integrally involved. Only by first positioning that letter in the details of this situation can we begin to get a sense of the nature of that relationship and its historical significance.

The precariousness of Eugenius's position in the fall of 1443 stemmed in part from an event that had taken place almost a year earlier. In November 1442, a German embassy had arrived at the papal court, then based in Florence, to present the proposal agreed to by the emperor and his electors that summer: that a new and undoubted council be convened as arbiter of the church conflict. ${ }^{26}$ The proposal did not fare well with Eugenius: maintaining that a legitimate church council was already in session in Florence, he rejected outright the proposal of calling a new one. ${ }^{27}$ Eugenius's response gave fresh momentum to the Basel assembly-for one, by convincing three of the electors that negotiating with the pope was futile. In the first few months of 1443, the electors of Trier, Saxony, and Cologne opened discussions with Felix V. While outwardly maintaining the policy of neutrality to which all German princes adhered, they agreed to endorse Eugenius's rival in exchange for generous

25. Stieber, 265; Baldi, Il "cardinale tedesco," 69; Gómez Canedo, 65-68. In the aftermath of the failed November diet, a disillusioned Piccolomini concluded that imperial diets simply produced other diets, rather than results: "Fecundae sunt omnes dietae, quaelibet in ventre alteram habet," Wolkan, ed., 62:318. The letter, also addressed to Carvajal, is dated 20 May 1444. For a discussion of the third Nuremberg Diet (1 August-11 October 1443), see Stieber, 266-69.

26. Stieber, $247-50$.

27. Stieber, 250. Eugenius's reply can be found in Deutsche Reichstagsakten unter Kaiser Friedrich III. Dritte Abteilung, 1442-1445, in Deutsche Reichstagsakten (Ältere Reihe), ed. Walter Kaemmerer (Stuttgart/Göttingen, 1963), 17:61-65. In 1437, Eugenius IV declared the Council of Basel transferred to Ferrara, where it met in 1438 . He did so in accordance with a decree passed by a minority of council fathers at Basel. The decision effectively split the original assembly at Basel into two rival councils. In 1439, the Council of Ferrara was transferred to Florence, on account of an outbreak of plague. On the Council of Ferrara-Florence, see especially Joseph Gill, The Council of Florence (Cambridge: Cambridge University Press, 1991), and Giuseppe Alberigo, ed., Christian Unity: The Council of Ferrara-Florence (1438/9-1989) (Leuven: Leuven University Press, 1991). 
rewards of money and privileges. They were also given attractive incentives to bring others to their side in time for the Diet of Nuremberg in November: if they could ensure that that assembly declared in favour of Felix, their payouts were to multiply significantly. ${ }^{28}$

For still other reasons, there was real concern in 1443 among Eugeniansand Carvajal specifically-that support for Felix would grow. In late January 1443, spokesmen for the Council of Basel had mounted a coordinated effort to drive a wedge between the pope and the other German rulers, including Frederick III. They did so by attacking the pontiff's formal written rejection of the proposed new council, issued in early December. In two treatises and a letter directed to Frederick, three of Felix's cardinals painted Eugenius's response as an act of hostility against the German nation. Among other things, they accused the pope of condemning Germany's position of neutrality in the church conflict, of questioning Frederick's legitimacy as emperor, and of equating support for a new council with heresy. ${ }^{29}$ The council's campaign of attack was carefully timed: Germany's rulers were scheduled to gather for the first Nuremberg diet just a few short weeks later (2 February) to revisit their proposal of the new council and to discuss Eugenius's response.

While the pope himself was the target of these assaults, it was his legate, Juan de Carvajal, who stood in the direct line of fire and who recognized the threat they posed. Late to the Diet of Nuremberg in February, he had no chance to defend the pope in person to the assembled envoys (the meeting had broken up before he had even arrived). He did, however, meet with the imperial delegation and then penned a brief response..$^{30}$ Of greater importance in the context of this investigation is what he did a few months later. In June, he delivered a substantially expanded version of this first document to a provincial synod in Mainz; and sometime between then and the Nuremberg

\section{Stieber, 251-59.}

29. For these documents, see Deutsche Reichstagsakten, 17:81-106. They consist of Cardinal Louis D'Aleman's letter to Frederick III, dated ca. 24 January-2 February 1443 (Deutsche Reichstagsakten, 17:81-86); Niccolò de Tudeschi's glosses on Eugenius's response, dated 16 January 1443 (Deutsche Reichstagsakten, 17:86-89); and Juan de Segovia's detailed analysis of Eugenius's response, dated to sometime after 13 January 1443 (Deutsche Reichstagsakten, 17:90-106). For a brief discussion of these documents, see Stieber, 251-52; and Gómez Canedo, 55-60.

30. Carvajal's response, dated 17-18 February 1443, is in Deutsche Reichstagsakten, 17:109-10. On this document, see Gómez Canedo, 55-60; and Stieber, 251. 
diet in November, he addressed a version of similar length directly to Frederick III. ${ }^{31}$ It is unclear whether the council's attack campaign had any effect on the emperor and the German princes. Nor do we know if they found Eugenius's response to the "third" council proposal insulting on its own. What we do know is that Frederick remained committed to that idea, and that, despite Eugenius's renewed opposition, he continued to promote it vigorously over the summer of 1443 in his letters of invitation to the Diet of Nuremberg. ${ }^{32}$ Carvajal's reasons for expanding his original work of apology may well be linked to these events. But regardless of what prompted those revisions, his decision to make them suggests that as the date of the diet approached, he remained concerned about Eugenius's standing in Germany, and particularly at the imperial court.

Those concerns were well founded for still other reasons. The problem lay with Eugenius's response to a different request from the imperial courtnot about the "third" council, but about a vacant benefice. On 16 August 1443, imperial chancellor Kaspar Schlick wrote to Eugenius to ask him to assign to his brother Heinrich the bishopric of Freising, one of the largest and wealthiest in the empire. ${ }^{33}$ More than a chancellor, Schlick was also Frederick's chief diplomat and a trusted advisor, and he had been one of the legates dispatched to Eugenius the previous November to present him with the proposal for a new, undoubted council. ${ }^{34}$ It was likely on that occasion that the pope had pledged to appoint Schlick's brother to a lucrative benefice in the future. For Eugenius, such an arrangement brought clear advantages: Kaspar Schlick would have represented a powerful ally at the imperial court, and an especially useful one at the end of 1442, given that Frederick was about to learn that his proposed "third" council had not met with the pope's approval. Eugenius would have seen still other advantages to assigning Schlick to the particular see of Freising. According to the chancellor, the emperor himself had expressed his preference

31. On Carvajal's presentation of his tract at the synod in Mainz, see Gómez Canedo, 60. Stieber is unaware of this longer version of Carvajal's response. See Gómez Canedo, 56-70; and for his edition of the text, 277-98.

32. Stieber, 264; Baldi, Il "cardinale tedesco," 58, 61-62. On 25 June 1443, Frederick wrote a letter asking Eugenius to reconsider his earlier response to the "third" council proposal. Eugenius responded in the negative on 25 August. See Deutsche Reichstagsakten, 17:152-53, 174-78.

33. Wolkan, ed., 62:59-60. For a discussion of the battle over the bishopric of Freising, see Stieber, 259-65 and Baldi, Il "cardinale tedesco," 62-63, 67-68.

34. Stieber, 259-65. 
for this appointment, and for good reason. The bishopric included temporal possessions in Frederick's own dynastic territories, which he was working hard to consolidate, and a seat on the royal council. ${ }^{35}$ Thus from the pope's standpoint, assigning the benefice to Heinrich was an effective way to earn the emperor's goodwill and precisely when their clash over the "third" council idea had left relations strained. In letters addressed to two of Eugenius's cardinals, Schlick lays out in tangible terms how the appointment of his brother could benefit the pope: "For through this [appointment] much favour will accrue to the curia," he explains to one cardinal, shortly after making the request to Eugenius, "and within Germany, his Holiness will have a greater following. Thus, little by little and through an indirect route, neutrality will be abolished." ${ }^{36}$ In early October, Schlick is still more explicit about how he will show his gratitude to Eugenius: "As you recommended," he informs the cardinal, "I will do everything I can to assist with the affairs of our Holy Father at the Diet of Nuremberg." ${ }^{37}$

Eugenius granted Schlick his request and made of him a powerful advocate-but this outcome was anything but guaranteed in mid-October 1443, when Piccolomini wrote to Carvajal. On the contrary, and much to the frustration of both chancellor and emperor, things at that point seemed headed in a very different direction. ${ }^{38}$ While Eugenius had affirmed Schlick's request soon after he had received it, he did not immediately send along the requisite letters of provision. At issue, it seems, were the annates, which Eugenius expected Schlick to pay in advance of his brother's investiture and in keeping

35. Schlick refers to these temporal holdings in letters he addressed to two cardinals in August. He also claims in his letter to Eugenius that the emperor wanted Heinrich in the position. See Wolkan, ed., 62:59-60, 61, 62-63.

36. "[N]am per hoc multum favoris sue curiae accrescet et major concursus ex Germania ad suam sanctitatem habebitur, sicque paulatim per indirectum neutralitas abolebitur," Wolkan, ed., 62:63. In a letter he wrote to another cardinal at about the same time, Schlick uses vaguer language to articulate how Heinrich's elevation to the bishopric of Freising will help Eugenius's cause: “[Eugenius] [...] me ad laborandum pro statu et honore suae sanctitatis semper promptum et paratum promtiorem et paratiorem reddet" ([Eugenius] will make me, who is always ready and prepared to defend the position and honour of His Holiness, still more ready and still more prepared). Wolkan, ed., 62:61.

37. "Negocia sanctissimi domini nostri, sicut mihi reccomendastis, in dieta Nurembergensi totis viribus adjuvabo," Wolkan, ed., 62:96.

38. Neither Stieber nor Baldi discusses this particular stage in the Freising affair. 
with traditional practices of papal provision. ${ }^{39}$ The delay of the letters created a serious problem and for more than just Schlick; in the interim, the cathedral chapter of Freising (claiming the right to fill the vacancy itself) elected someone else-Johannes Grünwalder, a cardinal of Felix V and the uncle of one of Frederick's greatest rivals in his Austrian territories. ${ }^{40}$ Without Eugenius's official letters of confirmation, Schlick did not have the means to defend his brother's claims to the see against Grünwalder's powerful allies. ${ }^{41}$ Schlick says as much in a letter he wrote to an unnamed cardinal in mid-October:

It is not enough for provision to have been made to my brother unless the letters [of confirmation] are also sent. I understand they are being detained in the [apostolic] camera because of the matter of the annates. If this is really true, then it is impossible for me to resist my rival. ${ }^{42}$

In another letter of the same date, Schlick expresses his frustrations to Eugenius directly. He complains that Grünwalder's allies were "attacking" the emperor daily through appeals from their ambassadors and through letters of support. ${ }^{43}$ He then lays the blame for this situation squarely at the pope's feet:

I, however, had foreseen all these things and had made them known to your Holiness. So I am a little surprised that the letters of provision are being held back on the condition of those annates. Your officials must have known that even with letters, and certainly not without them, I would scarcely be able to resist such an adversary, around whom all the

39. In a letter he wrote to an unnamed cardinal in mid-October, Schlick makes it clear that unpaid annates are the reason for the delay. Wolkan, ed., 62:102. Annates had been one of Germany's greatest grievances against the papacy. By making Heinrich's appointment hinge on their payment, Eugenius was testing Schlick's-and the emperor's-position on this papal privilege.

40. Stieber, 264.

41. Those allies included the archbishop of Salzburg, the Duke Albert of Bavaria, and the cathedral chapter of Freising. Wolkan, ed., 62:100.

42. "Parum esset, provisionem factam esse fratri meo nisi et litterae mitterentur, quas audio propter annatas detineri in camera. Quod si sic sit, impossible est, adversario me resistere," Wolkan, ed., 62:102. Schlick expresses similar anxieties in two other letters to cardinals written around the same time. See Wolkan, ed., 62:95-98.

43. Piccolomini uses the word "infestant." Wolkan, ed., 62:100. 
princes of Bavaria rally, whom the majority of prelates endorses, and who is not unfavourable in the eyes of all. ${ }^{44}$

What made that frustration so dangerous for Eugenius was that both Schlick and the emperor were simultaneously pursuing an alternative path to his brother's confirmation through the Council of Basel. Already at the end of August, the chancellor was writing to the Council's Cardinal Louis D'Aleman, recommending "the business of his dear brother Heinrich." ${ }^{45}$ By late September, the emperor had pressed the matter with the Basel council both in writing and through an embassy, promising that the assembly's favourable response to his request "will make [him] even more well-disposed than [he] already is to fulfilling the interests of the sacred council." ${ }^{46}$ In the end, the fathers at Basel did not satisfy the emperor's wishes; they chose instead to support those of Grünwalder. This outcome is well known in the scholarship, but its timing has been little discussed: they did not make up their minds until after the November Nuremberg diet. Nor have scholars considered possible causes for this delay. All things being equal, Grünwalder was the Basel council's obvious choice for the bishopric, but recent circumstances had changed that equation. When Frederick and his chancellor were pressing for Heinrich Schlick's nomination in the fall of 1443, Felix had already secured the support of three imperial electors. He must have recognized that by winning the favour of Frederick and his influential chancellor, he would be positioning himself brilliantly when the diet convened at Nuremberg a few weeks later. For Eugenius, on the other hand, it would have meant a perfect storm. ${ }^{47}$

44. "Ego tamen haec omnia praevideram vestraeque beatitudini insinuaveram, ideoque aliquantulum miror, retentas esse sub cuiusdam annatae colorae provisionis litteras, cum nosse debeant vestri officiales, vix me cum litteris, nedum absque illis, tanto adversario posse resistere, cuius latus omnes Bavariae principes stipant, quem prelatorum major pars iuvat et universitas non abhorret," Wolkan, ed., 62:100.

45. "Ultimo, reverendissme pater, recommendo paternitati vestrae reverendissime negotium domini Henrici germani mei carissimi," Wolkan, ed., 62:76.

46. "In qua re desideriis nostris plurimum complacebitis nosque ad sacri concilii commoda procuranda promptiores efficietis ex promptis," Wolkan, ed, 62:93.

47. Compounding Eugenius's problems were new political tensions on the Italian peninsula. See Baldi, Il "cardinale tedesco," 63-64. Baldi's recent interpretation complicates traditional scholarship, which emphasizes the strength of Eugenius's position after Alfonso of Aragon's withdrawal from the Basel council in June 1443. Stieber, 196-97. 
The details of these events are of such importance to this investigation because of Piccolomini's direct involvement at almost every step. It was he, as a member of the imperial chancery, who promoted the emperor's plan for a third council through the summer of 1443. In addition to writing the letters Frederick sent to Europe's princes, he drafted the one to Eugenius, in which the emperor asked the pope again to support his plan for peace. ${ }^{48}$ Piccolomini was also enlisted to help with the Freising affair, this time as both imperial secretary and good friend of the chancellor. He drafted all of Schlick's lettersto Eugenius and to his cardinals and also to D'Aleman-and he also wrote the letter that Frederick himself sent to the Basel assembly. ${ }^{49}$ Piccolomini then supplemented this correspondence with letters of his own. Two he addressed to the high-ranking D'Aleman, whom he knew well from his own years at Basel. In the first letter, dated 23 September, he writes:

You know, furthermore, how much influence the magnificent Chancellor Kaspar has with [the emperor]. [...] Win over this man, therefore, and conquer him with favours, especially now that the Diet of Nuremberg, which has been proclaimed throughout Christendom, is at hand. [...] For if [the Council's] confirmation of [Grünwalder] is not hastened, a great many roads will open up that will aid you and your party, and afterwards you will have the support of the majority in the Diet of Nuremberg. ${ }^{50}$

These same entreaties and promises appear in another letter to D'Aleman written only a few days before the one he penned to Carvajal in October:

I commend to your care the affair of the magnificent chancellor, so that this man, who is the right eye of the king [emperor] and his stronger hand, may advance the interests of the council, especially now that the diet of

48. See above, note 25 .

49. Wolkan, ed., 62:59-64, 75-76, 92-93, 95-102; Deutsche Reichstagsakten, 17:152-53.

50. "Scitis, praeterea, quantum apud eum possit magnificus Gaspar cancellarius. [...] Allicite igitur hunc virum et beneficiis devincite, maxime hoc tempore, quando dieta Norembergensis instat, quae per totam Christianitatem est vulgata. [...] Nam si confirmatio cardinalis non maturetur, aderunt viae, quae vestram partem juvabunt, plurimae, et vos postea in dieta Norembergensi majorem favorem habebitis," Wolkan, ed., 61:193-94. 
Nuremberg is at hand. [...] And [where] a decision will be reached, either about another council or about a declaration of allegiance. ${ }^{51}$

While echoing the promises of the chancellor and emperor, Piccolomini adds his own reason why the council should hurry to embrace his request: Juan de Carvajal and his powers of persuasion. Carvajal will be present at Nuremberg, Piccolomini warns D'Aleman, and with great skill he will continue to press Frederick and the princes to declare for Eugenius's cause. ${ }^{52}$ Just a few days before he wrote to the legate himself, then, Piccolomini was acknowledging Carvajal's power to influence the outcome of the conciliar crisis, even as he sought to exercise his own.

We have long known that the relationship between Carvajal and Piccolomini took root in the broader church conflict, but the above discussion serves to complicate that understanding in important ways. It does so first by exposing the acute nature of that crisis in the weeks and months before they exchanged their first extant letters. At the same time, it demonstrates how, in that context, both men played influential roles. When Piccolomini wrote to Carvajal on 23 October 1443, Eugenius and the Council of Basel seemed on the brink of a showdown-a showdown in which both men were deeply involved and whose outcome they were both in a position to shape. Given these circumstances, Piccolomini's relationship to Carvajal is one of particular historical interest: What exactly was their relationship, or more precisely, how did each one perceive it? And what influence, if any, did it have-or did they perceive it having-on what seemed like a critical stage in the conciliar conflict?

A close analysis of the 23 October 1443 letter gives us the chance to answer these questions, and from the perspective of both men. As he himself explains, Piccolomini wrote his letter in response to a substantial one that he had received from Carvajal. What the former writes, therefore, affords us the opportunity to listen indirectly to the voice of the latter. Listening to both voices allows us to see the different ways these two men perceived their relationship; and as the analysis below will demonstrate, those perceptions are important to

51. "Rem magnifici domini cancellarii vestrae curae commendo, ut hunc virum, qui dexter est oculus regis et manus fortior, concilium promoveat, nunc maxime cum dieta instat Norembergensis [...] et conclusio illic suscipietur aut alterius concilii aut declarationis," Wolkan, ed., 61:203.

52. Wolkan, ed., 61:194, 203. 
discern. On the eve of the Diet of Nuremberg, Carvajal and Piccolomini saw in their relationship with one another a powerful tool for navigating and even resolving the conciliar crisis.

Carvajal's missive preceded Piccolomini's and thus represents the natural starting point for this analysis. What had he said in his "long handwritten letter" ${ }^{53}$ Piccolomini does not summarize its entire contents, but he does indicate that it consisted of a series of arguments-historical, philosophical, biblical, and legal - in defense of Eugenius IV. From what he writes, moreover, several of Carvajal's specific points emerge. Piccolomini identifies more than half a dozen arguments with which he took issue. ${ }^{54}$ Those arguments fall into three main categories: ones that question the legitimacy of the Council of Basel at several points in time; ones that maintain the legitimate transfer of that council to Ferrara in 1437; and ones that deny secular rulers the right to exercise authority over the pope. In presenting these lines of argument, Carvajal was continuing to defend Eugenius's position on the "third" council proposed by the emperor: such a council was neither necessary nor sanctioned by law or precedent. They were the kinds of arguments that, as Eugenius's legate, Carvajal would have been preparing to present to the emperor and the German princes at the upcoming Diet of Nuremberg. To some extent, then, when he wrote his letter to Piccolomini, Carvajal was rehearsing his defence. But as the letter indicates very clearly, the legate had still another, more important purpose in mind. Piccolomini reports that Carvajal had made two significant requests of him in his letter: he had asked him to read it to the imperial chancellor, Kaspar Schlick; and he had also asked him to "praise and support" the arguments therein..$^{55}$

Drawing out Carvajal's voice in the 23 October letter reveals something very important-the importance that he himself attached to his relationship with Piccolomini at this point in the conciliar conflict. At a time when support for Eugenius at the imperial court was unravelling, Carvajal saw in that relationship the means of regaining traction and of redirecting the crisis toward a resolution favourable to the pope. Piccolomini could serve as a back channel

53. Piccolomini writes to Carvajal: “longum mihi misisti cirographum,” Wolkan, ed., 61:209.

54. Wolkan, ed., 61:209-10.

55. "Longum mihi misisti cirographum, ut cancellario legerem. [...] Rogas, quae a te scripta sunt, laudem tuearque," Wolkan, ed., 61:209. 
connecting Carvajal, and thus Eugenius, with the two most important figures at the imperial court: Frederick III and his chancellor, Kaspar Schlick. Based on the arguments outlined in Piccolomini's letter, that back channel was to serve a very particular need: to persuade the emperor to withdraw his support for the "third" council solution. It was increasingly important for Carvajal to make that case effectively as the Diet of Nuremberg drew near. At the same time, it had become increasingly complicated for him to do so-because of growing tensions between Eugenius, Schlick, and Frederick over the bishopric of Freising, and because of concern that the pope's earlier refusal of the emperor's plan had created long-lasting ill will at the imperial court. Under these circumstances, Piccolomini would have been useful to Carvajal simply as a messenger; indeed, the secretary's own friendship with Schlick made him the ideal one to communicate such a delicate message. That same friendship would also have made Piccolomini particularly effective as an advocate for Eugenius's position, for he could deliver it with the authority and credibility that Carvajal could not. In short, at a critical moment in the conciliar crisis, Carvajal sought to use his relationship with Piccolomini as the means of creating a political alliance in which Piccolomini would essentially serve as Eugenius's agent. That partnership must have seemed invaluable to Carvajal. In a time of crisis, it gave him the chance to accomplish what he and Eugenius had been struggling to do on their own.

This conclusion carries with it some important historiographical implications. In a recent edition of Piccolomini's correspondence, the October 1443 letter is grouped with others that he wrote with an eye to his own professional future. It is described as belonging to the period when Carvajal began serving as Piccolomini's "confidant and sponsor in the curia." ${ }^{6}$ There is no question that Carvajal did eventually fulfill that role. But the above analysis, which studies the letter in its contemporary context, rather than that of Piccolomini's future, suggests a different relationship altogether. In October 1443, it was Carvajal who sought Piccolomini as his confidant and sponsorand at the imperial, not the papal, court.

How, then, did Piccolomini respond to Carvajal's requests? His answers seem straightforward enough. He agrees to read the letter to Schlick ("I will do 
it when [the chancellor] has free time"), ${ }^{57}$ but he refuses to "praise and support" the legate's arguments wholesale. All told, Piccolomini devotes almost half his letter to rebutting individual points in Carvajal's case. "You want me to consent to these things," he says, concluding his extended counter argument; "I cannot." 58 In some sense, Piccolomini was still coming to Carvajal's aid when he drew up this critique. By systematically exposing and explaining the weaknesses he had found in the legate's arguments, he was serving as Carvajal's sounding board and just as the latter was preparing his defense for Nuremberg. Indeed, reading Piccolomini's response, the papal legate could glean which of his arguments were likely to fall flat before an audience of the emperor and the German princes. At the same time, he could learn which ones might give offence ("those claims should be fed to dimwits and people ignorant of history," Piccolomini exclaims in response to one of the legate's claims). ${ }^{59}$ This was useful information, indeed, given Carvajal's existing concerns about Eugenius's reputation at the imperial court. If in his letter Carvajal was rehearsing his arguments for the diet, then Piccolomini in his was acting the role of discerning audience. In so doing, he was serving as Carvajal's ally-just not on the legate's own terms.

But by engaging Carvajal in debate, Piccolomini was not so much reconfiguring the alliance proposed by the legate as he was defining a different one altogether. The nature of that relationship emerges as he prepares to counter Carvajal's claims. "You are my friend, I admit this," he tells the legate, after refusing to endorse his position, "but truth must be preferred." ${ }^{\prime 0}$ His words do not say that Carvajal had himself appealed to their friendship in his letter. Instead, they tell us what Piccolomini saw such an appeal would require: a blind loyalty to the legate's ideas. They also tell us that showing such loyalty would be a mistake because his—and, indeed, Carvajal's—responsibility should be to something higher. As articulated in the letter, Piccolomini's relationship with Carvajal was first and foremost that of two interlocutors united in a common quest for truth. For this reason, he prefaces his critique by explaining that truth is the standard by which he will measure the legate's arguments and determine their validity ("I will [support you] when I see you telling the truth; where I see

57. "Facturus sum, quando illi per otium licebit," Wolkan, ed., 61:209.

58. “Tu vis, me his consentire. Non possum,” Wolkan, ed., 61:210.

59. "Rusticis haec et historiarum ignaris narranda sunt," Wolkan, ed., 61:209.

60. “Tu mihi amicus es, fateor hoc. Sed veritas praeferenda est,” Wolkan, ed, 61:209. 
you doing otherwise, I will not. [...] I cannot stay silent if I hear something that is not true"). ${ }^{61}$ Carvajal should wholeheartedly approve, Piccolomini implies, for he sees him using the same criteria: "You believe that everything you write is true. I am confident about this since you are a man of integrity." ${ }^{2}$ Piccolomini then signals to the legate that his arguments have led him astray: "But what you write isn't true to the degree you think it is, and I will show you that in a few words." ${ }^{\prime 3}$ The second clause in this sentence is particularly important because it frames their relationship as a philosophical partnership: it is by challenging Carvajal's arguments, Piccolomini claims, that he will show him the pathway to truth. Piccolomini is describing here the essence of Socratic debate; and while he did not use that term explicitly in his letter to Carvajal, he had done so a few months earlier when discussing a similar exchange. In early 1443, Piccolomini had written to another member of Frederick's chancery, Hartung Von Kappel, to take up a debate they had begun in person in the halls of the imperial court. He explains how he saw that discussion unfolding and how he hopes it will continue: "[t]his, as Cicero says in the Tusculan Disputations, is the old Socratic method of arguing against the opinion of another. For Socrates considered this the easiest way to determine what was closest to the truth." ${ }^{64}$ That this was the

61. "Faciam id, si modo verum te dicere agnovero; ubi aliter videro, non faciam [...] non potero tacere, si quid non verum audiam," Wolkan, ed, 61:209. At the end of the letter, Piccolomini reiterates the truthfulness of what he writes: "Haec volui tibi dixisse cum venia tua, quia aut non loquor, aut vera loquor" (I wanted to say these things to you with your indulgence, because either I do not speak or I speak the truth). Wolkan, ed., 61:211.

62. “Tu vera omnia putas, quae scribis; hoc ego de tua probitate credo," Wolkan, ed., 61:209.

63. "Non tamen ita est, ut reris, quod tibi paucis ostendam,” Wolkan, ed., 209.

64. "Haec est enim, ut in Tuscullanis Cicero ait, vetus et Socratica ratio contra alterius opinionem disserendi. Nam et facillime, quid verisimillimum esset inveniri posse Socrates arbitrabatur," Wolkan, ed., 61:133. For the full letter, see Wolkan, ed., 61:132-44; and for an English translation, see Izbicki, Christianson, and Krey, eds., Reject Aeneas, 137-49. A few years earlier in his pro-conciliar history of the Council of Basel, Piccolomini had characterized the council fathers' debates in identical terms: "eamque ob causam congregatae adinvicem diutius inter se disputarent, aliis negativam, aliis affirmativam sententiam defendentibus, scientes hanc fuisse veterem et Socraticam rationem contra alterius opinionem disserendi. Nam ita facillime quid verisimillimum esset inveniri posse Socrates arbitrabatur" (Meeting together for that reason, they held a long discussion, some maintaining the negative, some the positive view, knowing that this was the old Socratic method of arguing against another's opinion. For Socrates thought that in this way what was closest to the truth could be most easily discovered). Piccolomini, De gestis, 16; English translation by Denys Hay and W. K. Smith on 17. 
kind of debate Piccolomini envisioned having with Carvajal in October 1443 seems confirmed by another letter he addressed to him a few months later. "Although we often debate matters of the Church," Piccolomini explains to the legate in May 1444, "that arguing is neither rancorous nor unyielding. Rather, it is the kind that used to be customary among philosophers, who would argue not to show off but to discern the truth." ${ }^{65}$

In contrast to this later letter, however, Piccolomini seems in his October 1443 missive to be not so much describing their relationship as he is reminding Carvajal of what it should be. The legate may well believe that he is making his case as a philosopher would ("You believe that everything you write is true" ${ }^{16}$ ), but his actions, Piccolomini argues, belie that claim. After concluding his rebuttal of Carvajal's argument, Piccolomini launches into a broader criticism of Eugenians and Baseleans alike and, in particular, of what he sees as their distinctly non-Socratic approach to resolving the conciliar conflict:

You also and your party want union, but on your terms-namely, that your pope remains pontiff and the church is unified. The other party also wants the same thing. Nobody rejects peace; nobody rejects union. But nobody embraces peace if it detracts from his own position. Everyone wants to win; nobody bends. Oh, men of stiff necks! ${ }^{67}$

Piccolomini's frustration here is palpable, as is his dismay at Carvajal. He condemns the legate's behaviour as that of a stubborn ideologue, not a philosopher; and he does so with a damning biblical allusion. ${ }^{68}$ The Book of

65. "Quamvis inter nos saepe de rebus ecclesiae concertatio sit, illa tamen non pertinax aut rancida est, sed qualis inter philosophos esse consuevit, qui non ut appareant sed ut inveniant verum disputant." Wolkan, ed, 61:318. Piccolomini would continue to frame discussions with Carvajal in these same terms after he himself had reconciled with Eugenius and had helped Frederick to do the same. See, for example, his August 1447 letter to the rector of the University of Cologne, where he describes the Socratic debates between conciliarists and papalists at the imperial court (Wolkan, ed., 63:56-57); and see also his 1463 bull In minoribus agentes, which mentions Carvajal by name (Fea, 159).

66. “Tu vera omnia putas, quae scribis,” Wolkan, ed., 61:209.

67. “Tu quoque et pars tua unionem velles, sed modo tuo. Maneat papa tuus pontifex et unio sit. Idem etiam pars altera cupit. Nemo pacem, nemo unionem aspernatur, nemo tamen pacem amplectitur, quae sibi detrahit. Omnes volunt vincere, nemo se flectit. Durae cervicis homines!” Wolkan, ed., 61:210.

68. Exod. $32: 9$ and $33: 3,5$. 
Exodus condemns the Israelites as "stiff-necked people" for worshipping a golden calf instead of God. Piccolomini's rebuke, is, thus, a harsh one, for it seems to imply that by embracing dogmatism, Carvajal is defying God's will. ${ }^{69}$ But even as he delivers this indictment, he recognizes in the legate the potential to change. His carefully reasoned rebuttal of Carvajal's arguments suggests this, as does his earlier and explicit acknowledgment of the legate's integrity. Carvajal, Piccolomini seems to be saying, has simply lost his way. His letter to the legate thus serves to remind him of his responsibility to truth and to the philosophical partnership that will lead him there. It also reminds him of what is at stake. No one else negotiating the conciliar conflict is capable of such dialogue, Piccolomini laments in the opening of his letter. They are all driven by their passions-so much so, in fact, that he vowed never even to try discussing with them the affairs of the church. ${ }^{70}$ By agreeing to engage Carvajal in debate, Piccolomini implies not only that he, Carvajal, is different but also that heand their philosophical partnership_bear considerable responsibility: for it is through this kind of dialogue, one that sees disagreements not as obstacles to consensus but as pathways to it, that the conciliar crisis can at last be resolved.

On 23 October 1443, Piccolomini had a very clear idea of what that resolution could look like, for his letter applies as well as champions this model of philosophical exchange. The arguments he puts forward to counter and "correct" those of Carvajal serve to legitimize as truth the emperor's case for summoning a new, undoubted council. They do so, in part, by challenging the legitimacy of Eugenius's transfer of the Basel council to Ferrara. Piccolomini makes his case with sound reasoning and solid evidence. He first questions Carvajal's defence of the conciliar decree that led to the assembly's alleged

69. On Piccolomini's anti-dogmatism, see especially Riccardo Fubini, "Enea Silvio Piccolomini nei suoi rapporti con la cultura umanistica del tempo," in Fabrizio Nevola, ed., Pio II Piccolomini: il Papa del Rinascimento a Siena: Atti del convegno internazionale di studi, 5-7 maggio 2006 (Siena: Protagon, 2009), 140 .

70. Piccolomini begins his letter: "Erat animus meus, postquam ex Basilea recessi, super rebus ecclesiae perpetuo uti silentio, cum eas non ex divini spiritus ductu regi, sed hominum gubernari passionibus viderem" (It was my intention after leaving Basel to keep silent forevermore on ecclesiastical matters. For it seemed to me that they were not being guided by the Holy Spirit but instead, were being governed by human passions), Wolkan, ed., 61:209. He is similarly bleak in a letter addressed to Cardinal Giuliano Cesarini on 28 May 1444, as he is looking ahead to the third of the Nuremberg diets: "Pauci sunt qui verum sequantur, omnes fere quod suum est quaerunt" (Few seek the truth; almost everyone looks out for his own interests), Wolkan, ed., 61:324. 
transfer-a decree that had won the support of only a minority of the council fathers. Reviewing the legate's claims, he writes:

You report that there are three cases in which the lesser part is able to take action against the will of the greater part of the whole. But actions of chapters and corporations, which answer to a superior, are not to be equated with the deeds of councils, where God alone is superior and no one can appeal from it. ${ }^{71}$

Piccolomini then questions another line of Carvajal's argument:

You say that at the Council of Constance full power was given to the Roman pontiffs to choose the place in which another council would be held. In [the Council of Basel's] case, the choice of the council's location was especially reserved to the council, just as the agreements made with the Greeks clearly show. ${ }^{72}$

Together, these arguments serve to delegitimize the council over which Eugenius was presiding at the time, and in so doing, open the door for a new, undoubted one to be convened. The idea that the emperor could take part in summoning such an assembly — and one invested with significant responsibility—is defended through an appeal to historical precedent. Piccolomini offers examples of popes granting substantial ecclesiastical powers to emperors, including authority over the papacy itself: "Pope Hadrian [I] and Leo [VIII] conceded to the Roman emperors the right to ordain the apostolic see and to name bishops in their realm." ${ }^{73} \mathrm{He}$ also points to Pope Leo the Great, who deferred to emperors on the question of where a council would be held:

71. "Refers, tres casus esse, quibus pars minor potest invita majori parte universitatis aliquid agere. Sed facta capitulorum et universitatum, quae superiorem habent, non sunt aequanda gestis conciliorum, ubi solum deus est superior et a quibus non appellatur," Wolkan, ed., 61:210.

72. "Dicis in concilio Constantiensi plenam potestatem datam esse Romanis pontifibius locum eligendi, in quo aliud celebrari concilium deberet. In casu nostro specialiter reservata fuit electio loci concilio, sicut conventiones cum Graecis habitae manifestant," Wolkan, ed., 61:210.

73. "Adrianus papa et Leo Romanis imperatoribus jus ordinandi apostolicam sedem et episcopos per imperium nominandi concesserunt," Wolkan, ed., 61:209. 
St. Leo, whom you and the Doctors of the Church call "the trumpet of the Gospel," wanted to hold a council in Italy, where many people could assemble from the regions of the West. But he yielded to Emperor Marcian, who was asking for a council in the East. Under these circumstances, the Council of Chalcedon took place. ${ }^{74}$

Piccolomini even cites a letter from Pope Leo IV to Emperor Louis II, in which the former pope proclaims himself willing to submit to correction by the latter: "If we did anything incompetently, or if we failed to preserve just laws for those in our care, we wish to amend all of it according to your judgment or that of your officials." 75 Piccolomini's arguments are carefully reasoned and grounded consistently in historical and legal evidence. ${ }^{76}$ They appear to upend Carvajal's convincingly and, at the same time, make a compelling case for his own opposing position. If Carvajal is indeed seeking the truth, then in Piccolomini's eyes, his response-and his responsibility-are clear: he must yield to these arguments, disavow Eugenius's transfer of the Basel council, and embrace Frederick's proposal of summoning a new church council to resolve the conciliar crisis.

Thus, the philosophical partnership that Piccolomini advocated in his letter was, in the end, the means to a political alliance-and one that in October 1443 was of considerable importance for the imperial secretary. As already discussed, Piccolomini had been pursuing very different paths to resolving the schism-by promoting the emperor's proposal for a new, undoubted council, and by trying to broker a deal with both Eugenius and the Basel fathers for the

74. "Leo ille sanctus, Italia concilium habere, in quo plures possent de occidentalibus partibus convenire, Marciano caesari, concilium in oriente postulanti, annuit. Tuncque synodus Calcedonensis habita est," Wolkan, ed., 61:209.

75. "Leo quartus scribit Ludovico Augusto: nos, si incompetenter aliquid egimus et in subditis justae legis tramitem non servamus, vestro ac missiorum vestrorum cuncta volumus emendare judicio," Wolkan, ed., 61:210.

76. In his reference to Popes Hadrian I and Leo VIII, Piccolomini was citing canon law, cleansed of the glosses of medieval canonists that had rendered it harmless to papal claims to sovereignty. See Walter Ullmann, Medieval Papalism: The Political Theories of the Medieval Canonists (London: Routledge, 1949), 172-73. His example of Leo IV, humbling himself before Emperor Louis II, is taken from Gratian's Decretum (Pars II. Caus. II Qu. III. c. 41). See Walter Ullmann, “'Nos si aliquid incompetenter ...'? Some Observations on the Register Fragments of Leo IV in the Collectio Brittanica," Ephemerides iuris canonici 9 (1953): 3-11. 
diocese of Freising. None of these efforts, however, had so far yielded results. With Nuremberg only weeks away, he needed to do what he could to assure that assembly's success. In his letter to Carvajal, he was doing just that, and in a familiar way: for just as Carvajal in his letter sought Piccolomini as an ally for his party, so did Piccolomini in his reply make the same, albeit more indirect, request of Carvajal.

That request was also fundamentally humanistic-and this, in turn, tells us something essential about the relationship between these two men. Most scholars who reference the October 1443 epistle acknowledge its humanistic dimension by noting the allusions to Virgil's Aeneid: Piccolomini describes himself in conversation with Carvajal as an "armed Aeneas" and then extends the parallel by referring to the pope as his "Anchises." 77 Clearly, Piccolomini expected Carvajal to recognize these references, as he did the allusions he makes to Terence's Eunuchus and Cicero's De officiis. ${ }^{78}$ But more important still, he must have known that Carvajal would be receptive to the role these texts were assigned in the letter. Piccolomini's classical references are not decorative, nor should they be misunderstood as a show of their author's erudition. On the contrary, they served in various ways to anchor and advance his argument. This is perhaps best seen in the allusion to Cicero towards the end of the letter. Contrasting his own approach with Carvajal's, Piccolomini writes that he would support any solution to the schism that both parties can agree upon, even if one party is left at a disadvantage ("incommodo suo"). ${ }^{79}$ To justify his position, he then turns to a well-known passage from the De officiis: "for we are not born for ourselves, but instead, we are born for the res publica." 80

77. Wolkan, ed., 61:209, 211. For references to these allusions, see Izbicki, Christianson, and Krey, eds., introduction to Reject Aeneas, 33; Zweder R. W. M. Von Martels, “'More Matter and Less Art': Aeneas Silvius Piccolomini and the Delicate Balance between Eloquent Words and Deeds,' in Pius II: 'El Più Expeditivo Pontifice.' Selected Studies on Aeneas Silvius Piccolomini (1405-1464), ed. Zweder R. W. M. von Martels and Arjo J. Vanderjagt (Leiden: Brill, 2003), 189.

78. Terence, Eunuchus, 1.2.23-25; Cicero, De officiis, 1.7.22. For a brief discussion of Carvajal and humanism, see Gómez Canedo, 269-72.

79. "Ego omnes commendarem, si viderem pacem his atque illis placere etiam cum incommodo suo," Wolkan, ed., 61:211.

80. "quia non nobis sed rei publicae nati sumus," Wolkan, ed., 61:211. This is a continuation of the sentence quoted in note 77 . Note that Piccolomini alters slightly the original passage in Cicero: "Sed, ut praeclare scriptum est a Platone, non nobis solum nati sumus ortusque nostri partem patria vindicat," De officiis, 1.7.22. 
Piccolomini is referring here to the res publica Christiana, and in so doing, uses Cicero's civic consciousness to prick Carvajal's Christian conscience. But he is also doing something more. The Ciceronian passage he chooses champions the precedence of public interest over private, and he enlists this hierarchy to make an important point. By equating ecclesiastical unity with the interests of the res publica, he effectively reduces the ideological positions of Eugenians and Baseleans alike to the interests of private individuals ("we are not born for ourselves"). Piccolomini had already equated dogmatism and self-interest earlier in the letter when decrying the stalemate in the conciliar conflict. "[N]obody embraces peace if it detracts from his own position ("quae sibi detrahit")," he lamented to Carvajal. "Has the Church become so submissive that it can be tossed about for the sake of one man's interests or another's?"81 By appealing to Cicero, Piccolomini enhanced that equation significantly, by giving it at once more clarity, more authority, and more force: in the context of the De officiis, Carvajal's loyalty to the Eugenian camp becomes a betrayal of the Christian community that he was obliged to serve. ${ }^{82}$ Humanism thus plays a vital role in Piccolomini's letter-by helping to delegitimize Carvajal's dogmatic approach to resolving the conciliar crisis.

At the same time, humanism equipped Piccolomini with other tools for resolving that crisis. It has already been noted how he sets up his discussion with Carvajal as a Socratic debate. That kind of debate was fundamentally humanistic: beginning with Petrarch, Italian humanists had been reviving and refashioning the classical dialogue, with Cicero and Plato as their central models. The genre had become a mainstay of humanist culture by the midfifteenth century-precisely when Piccolomini was writing to Carvajal. ${ }^{83}$ To

81.“[N]emo [...] pacem amplectitur, quae sibi detrahit. [...] Estne subjecta ecclesia, ut propter hunc vel illum hominem tam variae vexari debeat?” Wolkan, ed., 61:210.

82. In this way, the Ciceronian allusion builds directly on the biblical allusion discussed above.

83. For an introduction to Italian humanist dialogue in the fifteenth century, see especially David Marsh, The Quattrocento Dialogue: Classical Tradition and Humanist Innovation (Cambridge, MA: Harvard University Press, 1980). On the culture of disputatio and its central importance for Italian Renaissance humanism, see especially Christopher S. Celenza, The Lost Italian Renaissance (Baltimore: Johns Hopkins University Press, 2004), 86-88. See also Christopher S. Celenza and Bridget Pupillo, "La rinascita del dialogo," in Atlante storico della letteratura italiana, ed. vol. 1, Dalle origini al Rinascimento, ed. A. De Vincentiis (Turin: Einaudi, 2010), 341-47; and Christopher S. Celenza, The Intellectual World of the Italian Renaissance: Language, Philosophy, and the Search for Meaning (New York: Cambridge University Press, 2019), 73-80. 
be sure, the October 1443 letter does not follow the standard structure of the humanist dialogue, but its kinship with the genre is nonetheless evident and in several of its features. For one, Piccolomini frames his letter explicitly as a response to arguments Carvajal had put forward in a letter of his own. The way he writes, moreover, brings his interlocutor to life just as literary dialogues do: Piccolomini pauses to anticipate the legate's response to what he says and then takes his own cue from these imagined reactions ${ }^{84}$ Thus, like his similarly structured letter to Hartung Von Kappel, one that continues on paper a debate begun in person, Piccolomini's exchange with Carvajal can reasonably be read as "a dialogue at a distance." 85

But the letter is connected still more closely to the two more traditional dialogues that Piccolomini had written in the preceding months and years. The first was the aforementioned Libellus dialogorum (November-December 1440), a series of fourteen short dialogues with alternating pairs of interlocutors (Piccolomini and fellow humanist Martin le Franc; Nicholas of Cusa and canonist Stefano Caccia). ${ }^{86}$ The second and more recent was the Pentalogus (February-March 1443), a dialogue with five interlocutors (Piccolomini, Frederick III, and three of the emperor's closest advisors) held at the imperial court. ${ }^{87}$ In their subject matter, both texts share important common ground with the letter to Carvajal: in the Libellus dialogorum, Cusanus and Caccia debate whether Eugenius's transfer of the Basel council to Ferrara was legitimate; and in the Pentalogus, the speakers discuss, among other things, the emperor's right to call a church council. Not surprisingly, Piccolomini mines these works for specific arguments when writing to Carvajal. When, for example, he notes the precedent of popes ceding ecclesiastical authority to emperors, he uses the very same examples he had cited in the Pentalogus. He does so, moreover, in the context of his own exchange therein with imperial chancellor Kaspar

84. "Dices, me ex proposito errare, mihi adversus te magis haec opitulabitur allegatio, nichil ad me quis obtineat," Wolkan, ed., 61:210; "Scio te mihi jam irasci, quoniam dicta tua repello, quasi videar aliam tueri partem. Ne rere hoc," Wolkan, ed., 61:211.

85. This is how Baldi characterizes Piccolomini's letter to Von Kappel. Baldi, Il "cardinale tedesco," 54.

86. See above, note 8. The edition cited below is found in Adam Kollar, ed., Analecta Monumentorum omnis aevi vindobonensia, vol. 2 (Vienna: Ioannis V. Trattner, 1762), 691-790.

87. On this text, see especially Barbara Baldi, "Un umanista alla corte di Federico III: Il Pentalogus di Enea Sivlio Piccolomini," Cahiers d'études italiennes 13 (2011): 161-71; and Il “cardinale tedesco," 35-48; O'Brien, The Commentaries of Pope Pius II, 89-91. 
Schlick-the very person Carvajal sought as an audience for his letter. ${ }^{88}$ In turn, Piccolomini's reference to himself as an "armed Aeneas" seems to put into practice the ideal of debate that he champions in the Pentalogus ("because it is with letters, not with arms, that we must fight against the learned crowd"89) and in the same way that the Libellus dialogorum had done a few years before. In that text, the discussion between Cusanus and his interlocutor, Stefano Caccia, is framed as a series of battles, and the two are explicitly compared to ancient warriors: Scipio Africanus and Hannibal, and Hector and Achilles. ${ }^{90}$ They are also likened to characters in Terence's ancient comedy the Andria, ${ }^{91}$ and here, too, there is overlap with the October 1443 letter. There, Piccolomini describes himself as another Parmeno, the slave in Terence's Eunuchus, who "is full of cracks" and who "cannot stay silent when [he] hears anything untrue." ${ }^{92}$ As

88. When Schlick, one of the five interlocutors, asks on what authority the emperor can call a council, Piccolomini cites the same examples of Emperor Marcian and Leo I, Pope Hadrian and Pope Leo VIII. See Eneas Silvius Piccolomini, Pentalogus, ed. Christoph Schingnitz (Hanover: Hahnsche Buchhandlung, 2009), 134, 150. On this section of the dialogue, see O'Brien, The Commentaries of Pope Pius II, 90.

89. "[...] quia non armis contra multitudinem doctam, sed litteris est pugnandum," Piccolomini, Pentalogus, 110-12. It is also worth noting how Piccolomini defends his claim that a new, undoubted council will win the support of Europe's princes: "Nemo Christianorum principium ita deditus est Eugenio vel Felici ut non praeferat veritatem communeque bonum" (No Christian prince is so devoted to Eugenius or Felix that he would not prefer truth and the common good), Piccolomini, Pentalogus, 116. In his letter to Carvajal, Piccolomini calls on Eugenius's legate to do just that-to prefer truth and the common good to blind partisanship.

90. Piccolomini, Libellus dialogorum, 716; 719-20. The entire exchange, in fact, is staged as a battle. See, for example, how Cusanus begins the eight dialogue: "Marcum Marcellum, quo adversus Hannibalem Imperatore usi Romani sunt, saepe victum primo certamine, instaurasse praelis vires, vicisseque secondo in luctamine, scribit Livius, eadem modo spes est. Non potui ostendere transtulisse legitime se Concilium, translatum tamen esse ab alio Canonice, probaturum me non despero," Piccolomini, Libellus dialogorum, 738 .

91. After listening to the first exchange between Cusanus and Stefano Caccia, Martin le Franc observes to Piccolomini: "Scis, mihi ex Andria Terentii in mentem venit modo," Piccolomini, Libellus dialogorum, 715.

92. "Parmeno sum plenusque rimarum. Non potero tacere, si quid non verum audiam," Wolkan, ed., 61:209. In the lines immediately preceding these, Piccolomini writes: "Faciam id, si modo verum te dicere agnovero; ubi aliter videro, non faciam" (I will [support you] when I see you telling the truth; where I see you doing otherwise, I will not), Wolkan, ed, 61:209. All these lines are closely modelled on Parmeno's in Terence's comedy (Eunuchus 2.2.23-25): "Quae vera audivi, taceo et contineo optume; Sin falsum, aut vanum, aut fictum est, continuo palam est. Plenus rimarum sum, hac atque illuc perfluo" 
in the Libellus dialogorum, Piccolomini's allusion here to Roman comedy is playfully ironic: in the Eunuchus, Parmeno speaks this line to a prostitute, who is quarreling with her lover, Parmeno's master. But by invoking Terence in both these instances, Piccolomini is also doing something serious: he is signalling that the truth he seeks comes not from the tradition of medieval disputation but instead from the honest and open exchange between equals that was so favoured by his fellow humanists. ${ }^{93}$

That kind of exchange, in all three works, is assigned a momentous role, and it is here that Piccolomini's letter builds most significantly on his two earlier dialogues. Both the Pentalogus and the Libellus dialogorum make compelling cases that the humanist art of persuasion, exemplified by Socratic debate, was the key to effective diplomacy in the context of ecclesiastical politics. ${ }^{94}$ They do so in part through explicit arguments voiced by Piccolomini himself and, in the Libellus, also by his fellow humanist Martin le Franc. ${ }^{95}$ But they do so most powerfully by example-by modelling in a fictional setting just what such a dialogue looks like. In both works, individuals representing different sides of the conciliar conflict engage in discussion in search of "truth." 96

(The truths I hear, I keep secret; I contain them very well. But if anything's false or fanciful or fictional, it's out at once: I'm full of cracks, I leak all over), Terence, The Woman of Andros. The Self-Tormentor. The Eunuch, ed. and trans. John Barsby (Cambridge, MA: Harvard University Press, 2001), 300. Piccolomini also makes reference to the Eunuchus (3.5.8-12) in his letter to Hartung Von Kappel: "[A]t te nunc epistolam do, ut videas, tune an ego insaniam, ut Terentii verbis utamur," Wolkan, ed., 61:134.

93. For a discussion of the concept of truth in Renaissance humanism, see especially Charles Trinkaus, "The Question of Truth in Renaissance Rhetoric and Anthropology," in Renaissance Eloquence: Studies in the Theory and Practice of Renaissance Rhetoric, ed. (Berkeley: University of California Press, 1983), $207-20$.

94. On how the Pentalogus makes this case, see especially Baldi, Il "cardinale Tedesco," 35-48.

95. Several of Piccolomini's short conversations with LeFranc focus on criticizing the very different approach to disputation taken by contemporary theologians and jurists. See, for example, dialogue 3 (Piccolomini, Libellus dialogorum, 707-09) and dialogue 7 (Piccolomini, Libellus dialogorum, 734-38). These criticisms are a constant in Piccolomini's writings.

96. In the Libellus dialogorum, Stefano Caccia begins his debate with Cusanus by saying: "Socratico more contendemus; atque ita facillime, vel quod verum, vel quod verisimillimum est, inveniamus" (Piccolomini, Libellus dialogorum, 707). And in his preface to the text, Piccolomini introduces the sequence of dialogues in these terms: "[D]isputatio, sicut arbitror, et vobis facti dubietatem adimet, et aliis, qui minori Minerva sunt, ad veritatis inspectionem praestabit lumen" (Piccolomini, Libellus dialogorum, 693). 
Each interlocutor makes his case with evidence and reasoning, interrogates his opponent(s) with the same tools, and listens and responds to challenges to his own position. Just as important, Piccolomini models the outcomes of these discussions: he demonstrates that in the face of sound reasoning and compelling evidence, people can be persuaded to change their minds, find consensus, and thereby resolve their conflict. He illustrates this outcome most powerfully in the Libellus. The dialogue concludes when Cusanus concedes explicitly and gratefully to Stefano Caccia, won over by the "truth" he now sees in his opponent's case: "my mind and my opinion have changed, nor am I the same person I was a little while ago when I was talking with you. I do not know what has happened; but everything that you argued seems true, and what I argued in opposition, seems false. ${ }^{97}$ Cusanus's words here help to illuminate a deeper significance in the October 1443 letter. In his exchange with Carvajal, Piccolomini was essentially extending and applying to real-life diplomacy the ideal played out in these fictional debates: that humanist dialogue is the best vehicle for transcending ideological impasse and resolving the conciliar crisis. Of course, Piccolomini could not control Carvajal's response in the way that he could his fellow legate's in the Libellus dialogorum. But his letter encourages Carvajal, both explicitly and implicitly, to take the same path that Cusanus did and to follow it to the same conclusion: that truth lies not in his own position, but rather in the reasoned arguments of his opponent.

By addressing such a letter to Carvajal, Piccolomini tells us something important: that the two shared not just a cultural language but also a conviction that humanism could play a critical role in ecclesiastical politics and especially in the context of conflict. Thus, the letter bears witness to yet another kind of alliance between these two men, this one an alliance of letters, and one that was already well-established by the fall of 1443 . As such, it served as the foundation for the political alliance that each man sought to forge with the other at what was a crucial moment in the conciliar crisis.

97. "[M]utata mens mutatusque animus est, ne iam ille sum, qui paulo ante loquebar tecum. Nescio unde hoc est; jam omnia, quae disputata abs te sunt, vera, et quae contra objeci, falsa videntur" (Piccolomini, Libellus dialogorum, 787). While convinced of his new perspective, Cusanus is a loss to explain how it came about ("[n] escio unde hoc est"). He tentatively attributes it to divine inspiration, but in the end, makes no judgment. The dialogue's audience, however, will recall that at various points in the discussion Cusanus openly admits that Stefano is defeating him with his arguments. See, for example, Piccolomini, Libellus dialogorum, 733, 738, 775-76. 
Had that moment proven to be the decisive one in the church conflict, Piccolomini's relationship with Carvajal would likely have earned more scholarly attention than it has. But as this essay has illustrated, such scrutiny is clearly merited-and in spite of the apparent insignificance of the November Nuremberg diet. Piccolomini's letter of 23 October 1443 shows us that both he and Carvajal saw in their relationship with one another a powerful tool for resolving the schism that was roiling the church. Carvajal sought to forge a political alliance with Piccolomini in order to sway the emperor to Eugenius's side. Piccolomini, in contrast, appealed to Carvajal as a fellow humanist and philosopher in a way that would open the door for Frederick's "third" council solution. These findings serve to complicate in various ways our existing understanding of Piccolomini and Carvajal's relationship with one another. At the same time, they have brought into sharper focus the role each played in the conciliar crisis. Too often, scholars have relied on Piccolomini's own self-congratulatory (not to mention inconsistent) accounts for elucidating his role in this conflict. A close, contextualized scrutiny of his letters-and as exchanges, rather than simply expressions, of information and ideas-opens up an alternative and promising pathway for this investigation in the future. At the same time, this approach has allowed us to illuminate Carvajal's role in this crisis as Eugenius's embattled ambassador on the ground in Germany. But this essay has still broader implications for our understanding of the history of conciliarism. In the battle over sovereignty in the church, scholars have traditionally conceived of weapons in terms of ideas, money, and privileges. Piccolomini's October 1443 letter shows that the people fighting on the battlefield also leveraged something more intangible, more individual, and arguably just as powerful: their relationships with one another. 